\title{
ЭПИЗООТОЛОГИЧЕСКАЯ ОЦЕНКА РЫБ ВОДОЕМОВ АБШЕРОНСКОГО ПОЛУОСТРОВА
}

\section{Sh. A. Guliew}

\section{EPIZOOTOLOGICAL EVALUATION OF THE ABSHERON PENINSULA FISH POPULATION}

Гулиев Шукюр Аваз оглы - канд. биол. наук, доц., ст. науч. сотр. Института зоологии Национальной академии наук Азербайджана, Азербайджанская Республика, г. Баку.

E-mail: sh.quliyew@mail.ru

Абшеронский полуостров (западное побережье Каспийского моря) расположен в северной части Азербайджана. Здесь находятся многочисленные водоемы, водохранилище, Абшеронский водный магистральный канал. И столица Азербайджана - Баку, крупные города - Сумгаum, Хырдалан, и многие населенные пункты расположены на Абшероне. Население использует рыбу из этих водоемов в качестве пищи и может заразиться, если у этих рыб имеются опасные ихтиопаразиты. Поэтому иелью проведенных паразитологических исследований являлось определение видового состава, экологии, закономерности распределения и эпизоотологической ситуации патогенных паразитов рыб в водоемах Абшеронского полуострова и использование этих данных при создании новых рыбоводческих хозяйств. Исследования основаны на материалах, собранных при изучении 11 видов рыб в водоемах Абшеронского полуострова в 1993-2013 г2. Для определения видового состава патогенных ихтиопаразитов и распространения их по хозяевам в водоемах Абшеронского полуострова были исследованы 958 экземпляров рыб методом полного паразитологического вскрытия. Для исследований были использованы только свежие уснувшие рыбы. Все ткани и органы рыб были исследованы компрессорным методом при помощи бинокулярной лупы МБС-9, при увеличении × 25 . Из каждого органа делались мазки на предметных стеклах и исследовались под микроскопом Amplival, при увеличении $\times 1000$. В результате исследований в водоемах Абшеронского полуострова обнаружено 26 видов ихтиопаразитов,
Guliev Shukyur Avaz ogly - Cand. Biol. Sci., Assoc. Prof., Senior Staff Scientist, Institute of Zoology, National Academy of Sciences of Azerbaijan, Azerbaijan Republic, Baku.

E-mail: sh.quliyew@mail.ru

способных вызвать у рыб опасные заболевания. Зарегистрированы случаи заболевания рыб ихтиосттириозом, лигулезом, диплостомозом u аргулезом, воспалением плавательного пузыря и газопузырьковой болезнью, и т. д. Несмотря на многолетние паразитологические исследования рыб, в водоемах Абшеронского полуострова не найдено ихтиопаразитов, представляющих угрозу здоровью человека. Это означает, что рыб этих водоемов можно использовать в пищу. Но следует иметь в виду, что необнаружение опасных для человека паразитов не гарантирует их полное отсутствие 8 водоеме, поэтому и в будущем следует подвергать паразитологическому контролю рыб, употребляемых в пищу.

Ключевые слова: рыба, паразит, водоем, патогенность, заболевание.

The Absheron Peninsula is located in the northern part of Azerbaijan, on the western coast of the Caspian Sea. There are numerous water reservoirs, water basin and the Absheron main water canal. And the capital of Azerbaijan - Baku, large cities Sumgait, Khirdalan, and many other settlements are located on Absheron. The population uses fish from these resenvirs for food, and can become infected if these kinds of fish have dangerous ichthyoparasites. Therefore the purpose of conducted researches on parasitology was the definition of specific structure, ecology, regularity of distribution and an epizootological situation of pathogenic parasites of the fish in the reservoirs of the Absheron Peninsula and to use these data to create new fish farms. The studies were based on materials collected in the re- 
search of 11 fish species in the water bodies of the Absheron Peninsula in 1993-2013. To determine pathogenic ichthyoparasites' species composition and their distribution over the farms in the water bodies of the Absheron Peninsula, 958 fish specimens were examined by complete parasitological autopsy. For the study, only fresh, fallen asleep fish were used. All the tissues and organs of fish were studied by the compressor method using binocular magnifier MBS-9, at the magnification $\times 25$. The dabs on subject glasses were made of each body and were investigated under Amplival microscope, at the magnification $\times 1000$. As a result of the study, 26 species of ichthyoparasites were discovered in the water bodies of the Absheron Peninsula that could cause dangerous diseases in fish. The cases of fish disease with ichthyophthyroidism, ligulosis, diplostomosis and argulosis, inflammation of swimming bladder and gas-bubble disease were reported. It is gratifying that, despite the years of parasitological studies of fish, no ichthyoparasites have been found in the water bodies of the Absheron peninsula posing the threat to human health. This means that the fish of these reservoirs can be used for nutrition But it should be borne in mind that the failure to detect parasites dangerous to humans does not guarantee their complete absence in the reservoir, therefore, in future, all eaten fish should also be subjected to parasitological control.

Keywords: fish, parasite, reservoir, pathogenicity, disease.

Введение. Для полного удовлетворения спроса на рыбные продукты в Азербайджанской Республике проводилась большая работа. В Азербайджане есть множество водоемов, имеющих большие возможности для развития рыбного хозяйства. Водоемы Абшеронского полуострова в этом плане очень актуальны. Во-первых, на Абшеронском полуострове живет большая часть населения, а во-вторых, в этих водоемах водится рыба, которая употребляется в качестве пищи населением.

Актуальность изучения рыб с в водоеме паразитологической точки зрения состоит в том, как воздействовали паразиты на рыб и какие заболевания встречаются у этих рыб, есть ли опасные паразитические заболевания, представляющие опасности для рыб и человека.
Изучение паразитофауны является одной из важнейших задач и позволяет вовремя предотвратить некоторые заболевания, вызванные паразитами, и использовать рациональные методы борьбы с ними. И определение опасных паразитов, и разработка методов борьбы против этих паразитов позволяют улучшить состояние паразитофрауны в этих водоемах и повысить продуктивность рыб.

Цель исследований: определение видового состава, экологии, закономерности распределения и эпизоотологической ситуации патогенных паразитов рыб в водоемах Абшеронского полуострова и разработка методов борьбы с патогенными паразитами и различными заболеваниями рыб, а также использование этих данных при создании новых рыбоводческих хозяйств.

Материал и методика исследований. Исследования основаны на паразитологических материалах, собранных из исследованных 11 видов рыб в водоемах Абшеронского полуострова в 1993-2013 гг. Для определения видового состава ихтиопаразитов, в т. ч. и патогенных ихтиопаразитов, и распространения по хозяевам из водоемов Абшеронского полуострова были исследованы 958 экз. рыб методом полного паразитологического вскрытия. В результате исследования у этих рыб было обнаружено 75 видов ихтиопаразитов, из которых 26 видов оказались патогенными ихтиопаразитами. Для исследований были использованы только свежие уснувшие рыбы. Все ткани и органы рыб были исследованы компрессорным методом при помощи бинокулярной лупы МБС-9 при увеличении ×25. Из каждого органа делались мазки на предметных стеклах и исследовались под микроскопом Amplival при увеличении $\times 1000$.

Для диагностики всех паразитических групп были проведены измерения, и с помощью аппарата RA-4 были получены изображения.

Для оценки уровня зараженности были использованы следующие параметры: инвазионная интенсивность, инвазионная экстенсивность и индекс обилия.

Результаты исследований. Абшеронский полуостров в Азербайджане находится на западном побережье Каспийского моря, представляет собой юго-восточное окончание Большого Кавказского хребта. Абшеронский полуостров имеет длину около 60 км, ширину до 30 км. Водоемы 
Абшеронского полуострова характеризуются резкими перепадами ее температуры, достигающими в летнее время почти $30{ }^{\circ} \mathrm{C}$, связанным С этим десицитом растворенного в воде кислорода и периодическим частичным пересыханием, часто повышенной минерализацией воды. Будучи большей частью неглубокими, они подвергаются интенсивной солнечной радиации. Большинство водоемов загрязнено нефтью и нефтепродуктами, сточными водами из промышленных предприятий, различными химикалиями из сельскохозяйственных угодий и коммунальными отходами. Все водоемы в той или иной степени эвтрофицированы (табл.).

Такие, весьма тяжелые для обитания рыб, экологические условия, хотя, с одной стороны, способствуют обеднению паразитофауны рыб, с другой стороны, вызывая дополнительный стресс, усугубляют вредное воздействие паразитов на организм рыб. Кроме того, экстремальные условия сами являются причиной различных незаразных заболеваний рыб, таких как газопузырьковая болезнь, некроз жабр, различные отравления.

Из 75 видов ихтиопаразитов, отмеченных нами у рыб водоемов Абшеронского полуострова, 26 видов из литературных источников известны как возбудители следующих заболеваний рыб: $[1,5]$;

- криптобиоза жабр - Cryptobia branchialis

- костиоза - Costia necatrix [5];

- кокцидиозного энтерита карпа - Eimeria carpelli $[5,9]$;
- шишечной болезни усачей - M. muelleri (M. pfeifferi) $[5,8,9]$;

- хилодонеллеза - Chilodonella hexasticha и C. piscicola ) [1, 2, 5, 10];

- ихтиосртириоза - Ichthyophthirius multifilis $[2,5,10]$;

- апиозомоза - Apiosomapis cicolum [2, 9];

- триходиниозов - Trichodina nigra и Trichodinella epizootica [5];

- дактилогирозов карпа - Dactylogyrus extensus и $D$. vastator $[2,5]$;

- гиродактилеза карпа - G. katharineri [2, 3, 5];

- ботриоцесралеза карповых рыб - Bothriocephalus acheilognathi $[5,8]$ (этот паразит относится к видам дальневосточного комплекса и в водоемы Азербайджана занесен при проведении акклиматизационных мероприятий);

- лигулеза - Ligula intestinalis [3-5, 8];

- диплостомозов - Diplostomum chromatephorum, $D$. paraspathaceum, $D$. rutili и $D$. Spathaceum [5-7] (нами отмечены случаи помутнения хрусталиков гамбузии от воздействия $D$. Chromatophorum и D. rutili. Это происходило только, когда в одном хрусталике находилось более одного метацеркария диплостомумов);

- черно-пятнистой болезни - Posthodiplostomum cuticola [5, 7];

- эустронгилеза - Eustrongylides excisus [3, 4];

- писциколеза - Piscicola geometra [5];

- эргазилеза - Ergasilus briani и E. sieboldi [5];

- лернеоза - Lernaea cyprinacea [5];

- аргулеза - Argulus foliaceus [5, 9].

Распределение патогенных ихтиопаразитов по водоемам Абшеронского полуострова

\begin{tabular}{|l|c|c|c|c|c|c|}
\hline \multicolumn{1}{|c|}{ Паразиты } & Ган & Бюл & Ход & Дже & Аб-1 & Аб-2 \\
\hline \multicolumn{1}{|c|}{ 1 } & 2 & 3 & 4 & 5 & 6 & 7 \\
\hline Cryptobia branchialis & + & & & & + & + \\
\hline Costia necatrix & & & & + & + & \\
\hline Eimeria carpelli & & + & + & & + & + \\
\hline Myxobolus muelleri & + & + & + & + & + & + \\
\hline Chilodonella hexasticha & & & & + & + & + \\
\hline C. piscicola & + & & & + & + & \\
\hline Ichthyophthirius multifilis & & & & + & & + \\
\hline Apiosomapis cicolum & & & & + & + & + \\
\hline Trichodina nigra & + & & & + & & \\
\hline Trichodinella epizootica & + & & & + & + & + \\
\hline Dactylogyrus extensus & & & &
\end{tabular}


Окончание табл.

\begin{tabular}{|l|c|c|c|c|c|c|}
\hline \multicolumn{1}{|c|}{1} & 2 & 3 & 4 & 5 & 6 & 7 \\
\hline D. vastator & + & & & + & & \\
\hline Gyrodactylus katharineri & + & & & + & + & + \\
\hline Bothriocephalus acheilognathi & & & & + & + & \\
\hline Ligula intestinalis & & & & + & & + \\
\hline Diplostomum chromatophorum & + & + & + & + & + & + \\
\hline D. paraspathaceum & + & + & + & + & + & + \\
\hline D.rutili & + & + & & + & & + \\
\hline D. spathaceum & + & & + & + & + & \\
\hline Posthodiplostomum cuticola & + & + & + & + & + & + \\
\hline Eustrongylides excisus & & + & + & + & & \\
\hline Piscicola geometra & & & & + & + & \\
\hline Ergasilus briani & + & & & + & + & + \\
\hline E. sieboldi & & & & + & + & + \\
\hline Lernaea cyprinacea & + & & & + & & \\
\hline Argulus foliaceus & & & & + & + & + \\
\hline Число видов & 16 & 7 & 7 & 24 & 19 & 16 \\
\hline
\end{tabular}

Примечание. Сокращения в названиях водоемов: Ган - озеро Ганлыгель; Бюл - озеро Бюльбюля; Ход - озеро Ходжасан; Дже - Джейранбатанское водохранилище; Аб - Абшеронский магистральный канал (1 - первая часть Абшеронского магистрального канала, 2 - вторая часть Абшеронского магистрального канала).

В связи с тем, что большинство перечисленных паразитов имеет микроскопические размеры, они, как правило, вызывают патологические процессы в организме рыб только при высокой интенсивности заражения. Исключение составляют некоторые крупные фрормы, такие как цестода Ligula intestinalis и ракообразное Lernae acyprinacea, даже единичные особи которых становятся причиной заболевания.

Следовательно, наличие в водоеме некоторого числа патогенных видов ихтиопаразитов не означает, что у обитающих здесь рыб имеется такое же количество болезней. Однако в процессе проведенных нами полевых сборов мы зарегистрировали патологические изменения в организме определенной части обследованных нами рыб. Ниже мы приводим сведения об этих случаях.

Ихтиофттириоз. Ихтиофтириоз (белая точка) - заболевание рыб, вызываемое реснитчатыми инфузориями Ichthyophthirius multifiliis. Ихтиосртириозная инфеекция обычно заметна в форме белых точек на боку рыбы. Рыба также может необычно себя вести, например, трется о различные предметы. В мае 1995 г. на поверхности тела, плавников и жабр семи годовиков саза- на, добытого нами из озера Ганлыгель, было обнаружено большое количество патогенной инфузории Ichthyophthirius multifilis. Интенсивность инвазии составила от 98 до 270 экз. Поверхность тела и жабр сильно зараженных особей была покрыта толстым слоем слизи, жаберные лепестки были бледными. При вскрытии рыб выходило незначительное количество крови.

Лигулез. Это инвазионное заболевание рыб, вызываемое личинкой (плероцеркоидом) лигулы (ремнеца), половозрелая форма которой паразитирует в кишечнике некоторых рыбоядных птиц. Паразитируют они в брюшной полости рыбы и вызывают атрофию внутренних органов, бесплодие, нередко разрыв брюшной стенки и гибель рыбы. Хорошо выраженные симптомы этого заболевания отмечены у двух годовиков головля, выловленных из Джейранбатанского водохранилища, у одного годовика карася из озера Ганлыгель и у одного годовика карася из Абшеронского магистрального канала у пос. Герадиль (у каждого из них найдено по 2 экз. цестоды Ligula intestinalis), а также у двух сеголеток карася из озера Ганлыгель, у которых зарегистрировано по 1 экз. гельминтов этого вида. 
Больные рыбы были истощены, их брюшко было сильно вздуто, а вследствие сильного механического давления, которое оказывали тела червей на внутренние органы, печень и селезенка были уменьшены в размерах. У одного годовика карася из озера Ганлыгель и одного годовика карася из Абшеронского магистрального канала у пос. Герадиль, каждый из которых был заражен двумя экземплярами лигулы, под давлением червей произошел разрыв, стенки полости тела и гельминты свисали из образовавщейся сквозной раны. При вскрытии рыб пролилось незначительное количество крови.

Диплостомоз. Широко распространенное инвазионное заболевание рыб, возбудителем которого являются личинки (метацеркарии) дигенетического сосальщика из сем. Diplostomatidae. 3aраженность белого амура метацеркариями Diplostomum chromatophorum достигало 32 экз. Наблюдалось также смешанное заражение четыремя видами трематод рода Diplostomum $D$. chromatophorum, $D$. paraspathaceum, $D$. rutili $u$ D. spathaceum. У годовиков этой рыбы при наличии в одном хрусталике от 24 до 31 экз. диплостомумов различных видов наблюдалось помутнение хрусталика и, соответственно, слепота.

У гамбузии, которая является самой мелкой из исследованных нами рыб в этих водоемах, помутнение хрусталика происходило и при гораздо меньшей интенсивности инвазии метацеркариями. Эта рыба была заражена тремя видами трематод рода Diplostomum - D. Chromatophorum, D. paraspathaceum, D. rutili. Интенсивность инвазии каждым из этих гельминтов достигало только 2 экз., однако при смешанной инвазии превышало эту цифру. Так, в озере Ганлыгель в одном хрусталике гамбузии были найдены 3 метацеркария диплостомумов, в Абшеронском магистральном канале у поселка Герадиль в одном хрусталике гамбузии отмечено 2 метацеркария диплостомумов. При наличии в одном хрусталике гамбузии лишь одного метацеркария помутнения хрусталика не наблюдалось, при наличии же двух или трех происходило помутнение хрусталика.

Других значительных изменений в организме рыб, зараженных данным паразитом, например сильного истощения, визуально не наблюдалось.
Лернеоз. Эта болезнь - одна из опасных заболеваний рыбного населения не только рыб водоемов Абшеронского полуострова, но и рыб других водоемов. Сравнительно крупное ракообразное Lemaeacyprinacea, которое является возбудителем этого заболевания, отмечено нами по одному разу на поверхности тела уклейки в озере Ганлыгель и уклейки в Джейранбатанском водохранилище, два раза на поверхности тела карася в Джейранбатанском водохранилище, два раза на поверхности тела сазана в озере Ходжасан и один раз на поверхности тела у карася в озере Бюльбюля. Во всех случаях интенсивность инвазии этими ракообразными составляла 1 экз. В природных и искусственных водоемах Азербайджана эти паразиты, вызывая заболевание лернеоз у рыб, не только приносят большой ущерб рыбным хозяйствам, но и в большинстве случаев приводят к массивной гибели рыб при промысле. Болезнь, которую вызывают эти ракообразные (Lerneacyprinacea Linnaeus, 1758), является очень опасной не только для промысловых рыб в искусственных водоемах, но и для тех, которые живут в пресных природных водах.

Эти рачки, поселившиеся на теле исследованных рыб, образовав на коже сквозную рану, проникают своим хоботком в подкожные слои мускулатуры. Ткани вокруг раны были воспалены и отечны. Особенно хорошо заметны были патогенные процессы у зараженных уклеек, которые, будучи мелкими по размерам, сильнее страдали от воздействия этого паразитического ракообразного (Lemaeacyprinacea).

B процессе наших исследований мы отметили у рыб водоемов Абшеронского полуострова также одно заболевание, вызванное вирусами (воспаление плавательного пузыря) и одно незаразное заболевание (газопузырьковая болезнь). Несмотря на то, что наши исследования посвящены паразитам животного происхождения, мы считаем нелишним упомянуть и об этих двух болезнях тоже, так как они тоже являются очень опасными для рыб.

Воспаление плавательного пузыря. Острая форма этого заболевания отмечена у трех взрослых сазанов из озера Ганлыгель и двух взрослых сазанов из Абшеронского магистрального канала у пос. Герадиль. 
Больные рыбы в этих водоемах были очень ослаблены, слабо реагировали на внешние раздражители, плохо питались. Их брюшко было увеличено в области ануса. В полости тела накопилась жидкость красноватого цвета, стенки плавательного пузыря, брюшина и наружная поверхность кишечника были воспалены.

Газопузырьковая болезнь. Это заболевание возникает при резком понижении парциального давления газов, в особенности азота, во внешней водной среде, обычно в результате сильного повышения температуры. Часть газов, растворенных в крови рыб, образует пузырьки, которые скапливаются в тканях и полостях органов, могут закупорить кровеносные сосуды.

В августе 1998 г., при резком повышении температуры воды в озере Ганлыгель, мы наблюдали газопузырьковое заболевание у трех взрослых сазанов, а в 2003 г. - у двух взрослых сазанов. У больных рыб отмечены многочисленные пузырьки воздуха в коже плавников, головы, а также во внутренних органах - в почках и селезенке. Наблюдалась закупорка жаберных капилляров пузырьками воздуха.

Таким образом, у рыб водоемов Абшеронского полуострова отмечено 26 видов паразитов, которые по литературным данным способны вызвать в организме своих хозяев патологические изменения. Из них 2 вида относятся к жгутиконосцам, 1 вид относится к кокцидиям, а 1 вид - к миксоспоридиям, 6 видов относятся к инфузориям, 3 вида - к моногенеям, 2 вида - к цестодам, 5 видов относятся к трематодам, 1 вид относится к нематодам, 1 вид - к пиявкам и 4 вида относятся к ракообразным. Патогенная цестода Bothriocephalus acheilognathi занесена в водоемы Абшеронского полуострова человеком. Наибольшее число (24) видов патогенных ихтиопаразитов зарегистрировано в Джейранбатанском водохранилище, в Абшеронском магистральном канале отмечено 19 видов, в озере Ганлыгель и в Абшеронском магистральном канале у пос. Герадиль - по 16, в солоноватоводных озерах Бюльбюля и Ходжасан - по 7 видов паразитов. Заболеваний, вызванных большинством этих паразитов, во время наших исследований в водоемах Абшеронского полуострова не отмечено. Из заболеваний, вызванных паразитами животного происхождения, наблюдались: ихтиоффтириоз у сазана - Cyprinuscarpio, лигулез у голавля
- Squaliuscephalus и карася - Carassius, диплостомоз у белого амура - Ctenopharyngodon idella и гамбузии - Gambusia affinis, лернеоз у уклейки - Alburnus alburnus и карася, из заболеваний вирусного происхождения - воспаление плавательного пузыря у сазана - Cyprinuscarpio, из незаразных заболеваний - газопузырьковая болезнь у сазана.

Ихтиопаразитов, представляющих опасность для организма человека, у рыб водоемов Абшеронского полуострова не отмечено.

\section{Выводы}

1. В водоемах Абшеронского полуострова обнаружено 26 видов ихтиопаразитов, способных вызвать у рыб опасные заболевания. Кроме того, здесь зарегистрированы случаи заболевания рыб ихтиофтириозом, лигулезом, диплостомозом и аргулезом, воспалением плавательного пузыря и газопузырьковой болезнью. Это следует учитывать при проведении рыбохозяйственных мероприятий. Учитывая обнаружение в водоемах Абшерона опасного паразита цестоды Bothriocephalus acheilognathi, занесенного из Дальнего Востока, впредь при проведении любых рыбохозяйственных или мелиоративных мероприятий следует усилить паразитологический контроль.

2. В связи с тем, что все паразиты рыб, отмеченные в водоемах Абшеронского полуострова, в том числе и патогенные, являются пресноводными, фрауна ихтиопаразитов наиболее обеднена в солоноватоводных озерах Бюльбюля и Ходжасан, где обнаружено всего по 7 патогенных видов. Если рыбы, обитающие в этих водоемах, будут использованы для интродукции, риск занесения новых паразитов в другие рыбохозяйственные водоемы будет минимальным. Поэтому можно утверждать, что из рыб водоемов Абшеронского полуострова в паразитологическом отношении для интродукции наиболее пригодны те, которые обитают в этих солоноватоводных озерах.

3. Несмотря на многолетние паразитологические исследования рыб, в водоемах Абшеронского полуострова не найдено ихтиопаразитов, представляющих угрозу здоровью человека. Это означает, что рыб данных водоемов можно использовать в пищу. Однако следует 
иметь в виду, что необнаружение опасных для человека паразитов не гарантирует их полное отсутствие в водоеме, поэтому и в будущем следует подвергать паразитологическому контролю рыб, употребляемых в пищу.

\section{Литература}

1. Быховская-Павловская И.Е. Паразиты рыб: руководство по изучению. Л.: Наука, 1985. $122 \mathrm{c}$.

2. Гусев А.Б. Методика сбора и обработка материалов по моногенеям, паразитирующих у рыб. Л.: Наука, 1983. 47 с.

3. Казиева Н.Ш. Паразиты рыб Варваринского водохранилища: автореф. дис. ... канд. биол. наук. Баку, 1984. 20 с.

4. Кандилов Н.К. Эктопаразитические простейшие рыб бассейна реки Куры // Тр. Инта Зоологии АН АзССР. Баку, 1964. Т. 13. C. 134-149.

5. Микаилов Т.К. Паразитофрауна рыб водоемов Азербайджана (систематика, динамика, происхождение). Баку: Элм, 1975. 299 с.

6. Mikayılov T.K., Kazieva N.Ş. Varvara su anbarının parazitoloji durumu. Kürətrafı göllərin biologoyası. Bakı: Elm, 2001. $297 \mathrm{~s}$.

7. Маркевич А.П. Методика и техники паразитологического обследования у рыб. Киев: Изд-во Киев. гос. ун-та, 1950. 24 с.

8. Пашаев Г.А. К изучению гельминтозов рыб в Малом Гызылагачском нерестововырастном хозяйстве // Тр. АзНИВИ. Баку, 1968. T. 24. C. 155-157.

9. Süleymanova A.V. Abşeronbalıq əmtəə təsərrüfatı və Zabrat göllərində balıq parazitlərinin epizootoloji və epidemioloji durumu. Namizədlik dissertasiyasının avtoreferatı: Bakı, 2007, 20 s.
10. Klein B. Reaktion des Silberlinien-sistemy auf Shadlichkeiten.1. Ann. Ins. Sup. Arg., Milano, 1931, 4. S.71-73.

\section{Literatura}

1. Byhovskaja-Pavlovskaja I.E. Parazity ryb: rukovodstvo po izucheniju. L.: Nauka, 1985. $122 \mathrm{~s}$.

2. Gusev A.B. Metodika sbora i obrabotka materialov po monogenejam, parazitirujushhih u ryb. L.: Nauka,1983. 47 s.

3. Kazieva N.Sh. Parazity ryb Varvarinskogo vodohranilishha: avtoref. dis. ... kand. biol. nauk. Baku, 1984. $20 \mathrm{~s}$.

4. Kandilov N.K. Jektoparaziticheskie prostejshie ryb bassejna reki Kury // Tr. In-ta Zoologii AN AzSSR. Baku, 1964. T. 13. S. 134-149.

5. Mikailov T.K. Parazitofauna ryb vodoemov Azerbajdzhana (sistematika, dinamika, proishozhdenie). Baku: Jelm, 1975. 299 s.

6. Mikayılov T.K., Kazieva N.Ş. Varvara su anbarının parazitoloji durumu. Kürətrafı göllərin biologoyası. Bakı: Elm, 2001. 297 s.

7. Markevich A.P. Metodika i tehniki parazitologicheskogo obsledovanija u ryb. Kiev: Izd-vo Kiev. gos. un-ta, 1950. 24 s.

8. Pashaev G.A. K izucheniju gel'mintozov ryb v Malom Gyzylagachskom nerestovo-vyrastnom hozjajstve // Tr. AzNIVI. Baku, 1968. T. 24. S. $155-157$.

9. Süleymanova A.V. Abşeronbalıq əmtəə təsərrüfatı və Zabrat göllərində balıq parazitlərinin epizootoloji və epidemioloji durumu. Namizədlik dissertasiyasının avtoreferatı: Bakı, 2007, $20 \mathrm{~s}$.

10. Klein B. Reaktion des Silberlinien-sistemy auf Shadlichkeiten.1. Ann. Ins. Sup. Arg., Milano, 1931, 4. S. 71-73. 